\title{
'n Fenomenologie van rassisme: Hegeliaanse (wan)erkenning en die struktuur van koloniale bewussyn

\author{
A phenomenology of racism: Hegelian (mis)recognition and the structure of colonial \\ consciousness
}

\author{
Charles Villet
}

Navorsingsgenoot, Filosofie

Universiteit van die Vrystaat

Bloemfontein

Suid-Afrika

E-pos:VilletC@ufs.ac.za

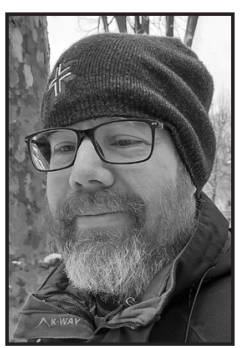

Charles Villet
Charles Villet is 'n navorsingsgenoot in die Departement Filosofie aan die Universiteit van die Vrystaat. Hy het vir digby twee dekades filosofie en etiek gedoseer aan verskeie tersiêre instellings in Johannesburg. Hy was van 2010 tot 2019 dosent en vakhoof in filosofie aan Monash South Africa (MSA). In 2019 verwerf hy sy PhD in sosiale en politieke denke aan die MonashUniversiteit, Melbourne. Die fokus van sy tesis, wat volg in Fanon en Foucault se voetspore, was op wit identiteit en erkenningspolitiek in SuidAfrika ná apartheid. Sy navorsing val breedweg binne die velde van postkolonialisme, witheidstudies, fenomenologie en kritiese teorie. Hy woon tans in Düsseldorf, Duitsland, waar hy verdere navorsing doen oor Hegel se meesterslaaf-dialektiek met betrekking tot erkenning in die postkoloniale konteks.
Charles Villet is a research fellow in the Philosophy Department at the University of the Free State. He taught philosophy and ethics at various tertiary institutions in Johannesburg for the best part of two decades. From 2010 to 2019 he was lecturer and discipline head in philosophy at Monash South Africa (MSA). He obtained a $\mathrm{PhD}$ in social and political thought from Monash University, Melbourne, in 2019. The focus of his thesis, following in the footsteps of Fanon and Foucault, was on white identity and the politics of recognition in post-apartheid South Africa. His research broadly falls within the fields of postcolonialism, whiteness studies, phenomenology and critical theory. He is currently based in Düsseldorf, Germany, where he continues researching the Hegelian master-slave dialectic as it relates to recognition in the postcolonial context.

\begin{abstract}
Ek is dankbaar vir die terugvoer van twee anonieme keurders; hulle kritiese voorstelle het grootliks bygedra tot die verskerping van hierdie essay. Ek is verder ook dank verskuldig aan die gehoor se kommentaar op ' $n$ vorige weergawe van hierdie essay wat as referaat by die 2019-kongres van die Nederlands-Afrikaanse Wysgerige Genootskap (NAWG) in Leiden, Nederland, gelewer is. Ek bedank ook die gasredakteur, Pieter Duvenage, vir sy hulp met die voorbereiding van hierdie essay vir publikasie asook Tom McLachlan vir sy deeglike taalversorging.
\end{abstract}

Datums:
Ontvang: 2021-04-12 Goedgekeur: 2021-05-18 $\quad$ Gepubliseer: September 2021


ABSTRACT

A phenomenology of racism: Hegelian (mis)recognition and the structure of colonial consciousness

This article critically discusses Hegel's account of the failure of mutual recognition (which Charles Taylor calls misrecognition) with specific focus on the master-slave dialectic. In this account, Hegel gives his analysis of a certain development in consciousness that leads to alienated self-consciousness in both the self and the other (subject and object). It is my view that the process which grounds this type of self-consciousness affords a phenomenological description and explanation of the cognitive roots of racism and violence as they are manifested in a so-called modern colonial mentality (in both the colonial and postcolonial context of European colonialism in Africa and elsewhere). In other words, Hegel's account gives us an exposition of how racism forms in self-consciousness. Considering racism, I chart a possible way to mutual recognition in order to see how misrecognition can be grappled with (in selfconsciousness). This is done by way of a model of Hegel's theory of consciousness, which is outlined in order to unpack the different types of intersubjective recognition. The focus of this model is the interaction between the phenomenological and conceptual aspects of Hegelian recognition in the encounter between the self (as subject) and the other. It is hoped that this model will promote understanding of the ways in which self-recognition, misrecognition and mutual recognition are connected to different forms of consciousness. Misrecognition and mutual recognition have a significant effect on intersubjective human relations as well as on the socio-political and economic reality of a society. Fanon highlighted this by focusing on the role of race as it concerns the dialectic and recognition.

Hegel charts the development of alienated self-consciousness in his account of the masterslave dialectic, and an understanding of this process is of crucial importance to the outline of mutual recognition provided in my study. This development may be summarised as follows: Self-consciousness distinguishes and identifies objects in the world and this level of consciousness can be termed bare existence. Consciousness is deepened as self-awareness when the self is distinguished as distinct from the world; this represents the split that takes place between the self as subject and the world (or the other) as object. Misrecognition as one-sided recognition is basically a continuation of object-centred recognition in human relations, and this kind of recognition distinguishes an other person simply as an object (who is thus reified). Misrecognition leads to a colonial consciousness with a colonial mentality in the self that grounds the alienated self-consciousness of the other through relations of racism and violence. Misrecognition gives form to a relation in which the self dominates the other to such an extent that they are alienated from each other. At the same time, the others feel alienated from their own selves and from the world around them because their sense of freedom is controlled by someone else. The ideal interaction with others that pays attention to issues of racism and violence would be some form of mutual recognition that distinguishes the other as a rehumanised subject (that is, a free person who can form his/her own identity). In this relation one also finds the ideal conditions for the self and the other to develop self-knowledge. This moment of Aufhebung (sublation) in the dialectic is a necessary step in overcoming the misrecognition inherent in the master-slave relationship, but it is also a postcolonial Aufhebung, which is different from the one that Hegel envisioned.

This study calls attention to a critical lacuna regarding the account of the master-slave relationship (which is also highlighted in the work of Frantz Fanon and could be viewed as a Fanonian moment in the dialectic). The reaction of the master to the slave (and vice versa) 
brings about a consciousness that holds ideas, or concepts, as primary. Therefore, the slave will be connected to an idea that the master has in his consciousness. This means that the slave's idea about himself is not of his own making. The nature of the self-consciousness that emerges in the slave (but also in the master) involves a relation of alienation and the development of alienated self-consciousness. This kind of self-consciousness has to do with two key problems: Firstly, the negation, absence or denial of humanity in self-consciousness in so far as it concerns relations with others, for instance in the case of race, and secondly, the ideas generated because of this negation/absence/denial, which are attached to the racial other and lead specifically to misrecognition. Such ideas are sometimes combined in single terms or words (e.g. derogatory racist terms as labels). In the end, my study demonstrates how reification through concepts (as misrecognition) in Hegel's master-slave dialectic leads to the phenomenon of race and racism.

KEYWORDS: $\quad$ alienated self-consciousness; Aufhebung (sublation); colonial mentality; colonialism; Frantz Fanon; Georg Hegel; intersubjectivity; master-slave dialectic; misrecognition; mutual recognition; phoney recognition; postcolonialism; racism; reification; self-consciousness; self and other; struggle for recognition

TREFWOORDE: Aufhebung; erkenning; Frantz Fanon; Georg Hegel; intersubjektiwiteit; koloniale mentaliteit; kolonialisme; meester-slaaf-dialektiek; postkolonialisme; rassisme; selfbewussyn; self en ander; stryd om erkenning; vervreemde selfbewussyn; valse erkenning; wanerkenning; wedersydse erkenning; verdingliking (reïfikasie)

\section{OPSOMMING}

Hierdie artikel neem Hegel se weergawe van die mislukking van wedersydse erkenning (dus wanerkenning) krities onder die loep met spesifieke fokus op die meester-slaaf-dialektiek. Hegel gee daarmee sy analise van 'n soort bewussynsontwikkeling wat lei tot vervreemde selfbewussyn in sowel die self as die ander (subjek en objek). Die proses wat hierdie soort bewussyn begrond, gee myns insiens ' $n$ fenomenologiese beskrywing en verduideliking van die kognitiewe wortels van rassisme en geweld soos wat dit gemanifesteer word in 'n sogenaamde moderne koloniale mentaliteit (beide in die koloniale en die postkoloniale konteks). Dit bied met ander woorde 'n uiteensetting van hoe rassisme vorm aanneem in die selfbewussyn. Die moontlike wegbeweeg van rassisme na wedersydse erkenning word ondersoek met die doel om te sien hoe wanerkenning hanteer kan word (in die selfbewussyn). Dit word gedoen aan die hand van 'n model van Hegel se bewussynsteorie, wat verskillende soorte intersubjektiewe erkenning in breë trekke uiteensit. Die fokus van hierdie model is die wisselwerking tussen die dinglike en begripsaspekte van Hegeliaanse erkenning in die interaksie van die self (as subjek) met die ander. Hopelik kan hierdie model help om begrip te bevorder van hoe selferkenning, wanerkenning en wedersydse erkenning gepaard gaan met verskillende vorme van bewussyn. Teen die agtergrond van 'n koloniale bewussyn het wanerkenning en wedersydse erkenning 'n beduidende uitwerking op menslike verhoudinge. Fanon het dit verder belig met sy fokus op die rol van ras in die dialektiek en erkenning. 


\section{INLEIDING}

Die vertrekpunt van hierdie studie is die vraag na presies wat in die bewussyn van die self tot rassisme teenoor die ander lei. Die artikel doen aan die hand dat 'n moderne koloniale bewussyn die fondament vir rassisme lê. In die werk van Hegel kan een van die eerste duidelike teorieë oor erkenning gevind word; die fokus daarvan is die ontwikkeling van selfbewussyn. Ek ondersoek hoe Hegel hierdie kwessie aanpak en beskou die mislukking van wedersydse erkenning (dus wanerkenning ${ }^{2}$ ) spesifiek in sy weergawe van die meester-slaaf-dialektiek. Ek neem sy analise van die bewussynsontwikkeling wat tot wanerkenning lei, onder die loep met drie vrae in gedagte: Eerstens, hoe word selfbewussyn gevorm in die Hegeliaanse paradigma? Tweedens, hoe lei hierdie vorming tot wanerkenning en die gevolglike vervreemding van selfbewussyn (as grondslag van rassisme)? En derdens, wat is die nodige voorwaardes in die selfbewussyn vir wedersydse erkenning in die lig van hierdie probleem? Wanerkenning lei tot vervreemde selfbewussyn en begrond die kognitiewe wortels van rassisme en ongeregtigheid. 'n Analise van hierdie proses met behulp van die werk van sowel Hegel as Fanon gee vir ons 'n fenomenologie van die vorming van rassisme en die moontlike wegbeweeg daarvandaan na wedersydse erkenning. Hierdie fenomenologie demonstreer hoe verdingliking of reïfikasie deur middel van begrippe (as wanerkenning) in Hegel se meester-slaaf-verhouding lei tot die fenomeen van ras en rassisme as een van verskeie vorme van wanerkenning. Hierdie vorm van wanerkenning begrond ' $n$ sogenaamde koloniale mentaliteit in die self (in die koloniale en postkoloniale konteks) wat aanleiding gee tot 'n vervreemde selfbewussyn in die ander. Die oorspronklike bydrae van my studie lê in die fokus op die self en dit wat plaasvind in die bewussyn van die self wanneer wanerkenning rassisme is, en voorts in hoe hierdie probleem in selfbewussyn aangepak kan word.

\section{MEESTER EN SLAAF: DIE HEGELIAANSE MISLUKKING VAN WEDER- SYDSE ERKENNING (WANERKENNING)}

Die bekendste weergawe van Hegel se meester-slaaf-dialektiek (ook genoem heer en kneg, lord and bondsman) verskyn in sy "Fenomenologie van die Gees"3 (Hegel 1977:111-119; oorspronklik gepubliseer in 1807). Die fokus is op die stryd om erkenning (Duits: Kampf um Anerkennung) wanneer twee persone mekaar teëkom. 'n Eis van elk van die partye om erkenning deur die ander vind plaas en daarna volg 'n struweling om lewe en dood (ibid. 114). Die een wat oorgee, word die slaaf en word verder erken as 'n objek wat vir sy arbeid uitgebuit moet word. Hierdie uitbuiting verg 'n sekere soort verdingliking (of selfs verdierliking, pace Fanon (1986:220)) van die slaaf om hom op sy plek te sit (Hegel 1977:115). Hierdie verhouding is wel paradoksaal: Die meester bly afhanklik van die slaaf om homself te definieer en te beskou as meester (ibid. 116-117). Die slaaf voed hom onderweg na onafhanklikheid omdat die wêreld rondom hom die resultaat is van sy eie handewerk (arbeid). Die idees van daardie wêreld word in wisselwerking met die slaaf deur die meester ontwikkel, en dus kan die slaaf

2 Die term 'wanerkenning' word vervolgens gebruik in die artikel om te verwys na die manier waarop hierdie soort erkenning lei tot iets soos 'n wanbeeld van die ander. Dit kan oor die algemeen ook verwys na verkeerde of foutiewe erkenning.

3 Vir hierdie artikel is Phenomenology of Spirit, AV Miller se vertaling van die oorspronklike Phänomenologie des Geistes, gebruik. Vir die doel van hierdie artikel word Fenomenologie geriefshalwe as 'n verkorte Afrikaanse vertaling van die titel gebruik. 
ook daaraan werk om hierdie idees te verander (ibid. 118-119). Die verhouding het op die ou end twee uitkomste: Die voortsetting daarvan aan die hand van konflik waarin geweld en/of rassisme wedersydse erkenning onmoontlik maak, of andersins bemiddeling deur idees wat ten doel het om wedersydse erkenning te bereik. Laasgenoemde lei tot sogenaamde Aufhebung (sublasie), waar die verhouding oorbrug word deur aan te beweeg na 'n volgende stap in die dialektiek. Wat belangrik is om in ag te neem, is dat Hegel 'n kardinale rol toeken aan idees en 'n konseptuele verstaan van die verhouding tussen persone.

Die punt van Hegel se siening van die meester en slaaf in Fenomenologie is om aan te toon dat intersubjektiwiteit van kardinale belang is vir selfbewussyn en die stryd om erkenning. Die stryd om erkenning is 'n stryd juis vanweë hierdie intersubjektiwiteit, dit wil sê dit vind plaas tussen twee of meer partye wat elk sy eie vryheid wil laat geld. Dit beteken egter nie dat die vorming van selfbewussyn volledig van intersubjektiwiteit afhang nie, maar dat 'n verdieping en vervulling van selfbewussyn slegs deur intersubjektiewe erkenning moontlik is. Intersubjektiewe erkenning bied aan selfbewussyn die moontlikhede van selftransendensie en selfontwikkeling. Hierdie moontlikhede lê in die dinamiese beweging wat kan ontwikkel om beter selfkennis te bekom aan die hand van intersubjektiewe kontak met die ander. As hierdie moontlikhede egter ontbreek, dan word selfbewussyn leeg getap; dit is wat met die Hegeliaanse slaaf gebeur.

Die bekendste weergawe van die deurslaggewende rol van intersubjektiwiteit is vervat in die eerste sin van die bespreking oor die meester en slaaf (Hegel 1977:111): "Selfconsciousness exists in and for itself when, and by the fact that, it so exists for another; that is, it exists only in being acknowledged". By nadere ondersoek beweer Hegel nie dat intersubjektiwiteit nodig is om selfbewus te word nie, maar dat selfbewussyn bemiddel word deur erkenning van sigself deur 'n ander. Daarom word intersubjektiwiteit reeds in die meesterslaaf-dialektiek gevind, en so ook die erkenning van die verskynsel (fenomeen) van die ander. Hegel (ibid. 184) beweer dat beide die meester en die slaaf deur bemiddeling van die ander hulself erken in die wedersydse erkenning van mekaar. Met ander woorde, ek sien dat jy my erken en dit lei daartoe dat ek jou erken (en ook myself deur jou erkenning). Hierdie wedersydse erkenning op 'n fenomenaal-sintuiglike vlak is egter nie noodwendig 'n bewys van die wedersydse erkenning van die menslikheid van 'n ander nie. Ek sê dit omdat Hegel (ibid. 185) verder aanvoer dat die suiwer begrip van erkenning aanvanklik die kant van die ongelykheid van die twee sal vertoon, wat lei tot twee uiterstes (dit wil sê meester en slaaf) wat teenoor mekaar staan in 'n verhouding van die een wat erken word en die ander wat bloot hierdie erkenning gee. Hierdie ongelykheid lei tot eensydige erkenning, wat Taylor (1994:2526) mis-erkenning (misrecognition) noem of wat Williams (1997:64) valse erkenning (phoney recognition) noem.

Hierdie wanerkenning vind plaas wanneer die self die ander as 'n objek onderskei, wat gekontrasteer kan word met die gee van wedersydse erkenning om die ander as subjek te onderskei. Die ander word vervolgens verdinglik (gereïfiseer) en dit lei tot wanerkenning en die vervreemde selfbewussyn, dit wil sê 'n kortgeknipte selfbewussyn in die ander wat geen betekenis aan sy eie leefwêreld gee nie. Die kern van die saak word duidelik: In basiese, konkrete intersubjektiewe betrokkenheid is onderlinge erkenning moontlik, maar dit kom nie noodwendig neer op 'n konseptueel-diskursiewe erkenning van die menslikheid van die ander of van die ander as subjek nie. Die verdieping van selfbewussyn kan nie sonder kontak met 'n ander plaasvind nie; tog kan hierdie verdieping kortgeknip word as die wedersydse erkenning nie op 'n epistemologies-konseptuele vlak voortgaan nie, dit wil sê op die vlak van begrip. 
Die kern van Hegel se meester-slaaf-dialektiek is die samestelling van die subjek-objekverhouding in die gee van betekenis deur die subjek (die meester) aan die objek (die slaaf). Die dinamiek van die wisselwerking tussen subjek en objek word deur Hegel se meester-slaafdialektiek uitgelig: Die subjek is die individu wat sy eie identiteit kan begrond en die betekenis van hierdie identiteit (en dus van die wêreld) kan vorm. Die objek is 'n individu wat nie hiertoe in staat is nie omdat die betekenis van sy identiteit afhang van die subjek en dus by iemand anders berus. Betekenis word dus gevorm aan die hand van hoe die subjek die objek begryp. Anders gestel, die objek moet hom as verskynsel onderwerp aan die subjek se betekenisgewende gesag, en Hegel beskryf hierdie proses.

Die verband tussen verskynsel en konsep blyk die kern te wees van Hegel se ontleding van selfbewussyn en, nog belangriker, die kern van sy begrip van erkenning en die gebrek aan wedersydse erkenning (dit wil sê wanerkenning). Hegel se ontleding is fenomenologies belangrik, maar die begrip van die ander as verskynsel aan die hand van die konsep waarmee die verdingliking van die ander verder gevoer word, is eties problematies. Dit is 'n problematiese neiging of gewoonte wat die opkoms van selfbewussyn in die algemeen belemmer, maar mens moet in ag neem dat Hegel ' $n$ beskrywende weergawe van die proses gee, nie 'n normatiewe weergawe nie. Hierdie neiging of gewoonte word duidelik as 'n mens kyk na Hegel se weergawe van die presiese oomblik waarop selfbewussyn te voorskyn kom in die "Ensiklopedie III: Filosofie van die Gees"4 (Hegel 1971:164-165):

...consciousness as such implies the reciprocal independence of subject and object. The ego in its judgement has an object which is not distinct from it - it has itself. Consciousness has passed into self-consciousness. ... Self-consciousness is the truth of consciousness: the latter is a consequence of the former, all consciousness of an other object being as a matter of fact also self-consciousness. The object is my idea: I am aware of the object as mine; and thus in it I am aware of me. The formula of self-consciousness if I = I: - abstract freedom, pure 'Ideality'.

Hier lyk dit asof Hegel 'n onderskeid tref tussen bewussyn en selfbewussyn met die aanname dat selfbewussyn die voortsetting (of logiese vordering) van bewussyn is. Die oorgang van bewussyn na selfbewussyn lyk onvermydelik en dit lui 'n paar belangrike momente in: Eerstens bring selfbewussyn 'n verhouding van wedersydse afhanklikheid tussen die subjek en objek (dit wil sê die self en 'n ander) tot stand, ten minste op die basiese vlak van objekte. Tweedens objektiveer selfbewussyn sigself as 'n subjek (die self) wat met ander objekte in die wêreld kan kommunikeer. Hierdie twee oomblikke verteenwoordig die oorgang van bewussyn na selfbewussyn. Op hierdie punt word die rol van idees (konsepte) belangrik omdat dit deel is van die poging van die selfbewussyn om die sekerheid of waarheid van sy idees oor die wêreld en natuurlik die ander te laat geld.

'n Mens sou kon sê dat die verbinding van konsepte aan verskynsels binne die Hegeliaanse paradigma onvermydelik is vir die verdieping van selfbewussyn. In werklikheid is hierdie verbinding ook van kardinale belang vir selfbewussyn om intersubjektief betrokke te raak by die wêreld. Hierdie verbinding word vereis om eksplisiete kennis van die self en ander te bereik. Dien Winfield (2006:778) verwoord hierdie vereiste soos volg: "[P]reverbal intersubjectivity in which nondiscursive self-consciousness resides can hardly involve self-

$4 \quad$ Vir hierdie artikel is Encyclopaedia of the Philosophical Sciences, Part III: Philosophy of Mind, JN Findlay se vertaling van Enzyklopädie der philosophischen Wissenschaften im Grundrisse, gebruik. 
knowledge or knowledge of others." Dit blyk dus dat die verbinding van konsepte aan verskynsels 'n noodsaaklike stap is vir die verdieping van selfbewussyn wat sigself beskou as 'n onderwerp van kennis. Vir Hegel vind hierdie verbinding en verdieping van selfbewussyn plaas in intersubjektiewe betrokkenheid.

\section{DIE ONTWIKKELING VAN SELFBEWUSSYN DEUR VERDINGLIKING EN BEGRIP}

Die verdieping van selfbewussyn deur intersubjektiewe erkenning binne die Hegeliaanse paradigma vereis twee belangrike sake wat naas mekaar in die interaksie met ander objekte voorkom, dit wil sê dit is twee aspekte van dieselfde ervaring. Die eerste aspek is 'n basiese en onmiddellike erkenning van die ander, wat 'n erkenning is van die werklike bestaan van die konkrete ander, dit wil sê intersubjektiewe erkenning in sy dinglike aspek (as verskynsel of fenomeen). Die tweede aspek is die refleksiewe erkenning van die ander, wat 'n konseptuele refleksie deur selfbewussyn van die ander aantoon, wat lei tot 'n diskursiewe erkenning of erkenning in sy begripsaspek (as konsep). Wat belangrik is om by hierdie begripsaspek in ag te neem, is dat dit 'n mens die kans gee om die ding te begryp, wat 'n soort verstaan van die ding is, maar tog meer is, aangesien "gryp", waarop "begryp" teruggaan, onder meer beteken "iets vir jouself neem, toe-eien". Begrip is dus die manier waarop selfbewussyn hom iets as sy eie toe-eien. Dit is hoe mag uitgeoefen kan word oor die ding wat nou joune is, omdat jy die een is wat betekenis aan die ding verleen. So word begrip dan 'n verdere konseptuele verdingliking van die ander. ${ }^{5}$

Die dinglike aspek van Hegeliaanse erkenning spruit voort uit die beliggaamde aard van selfbewussyn. Daarom vereis die interaksie met die ander ' $n$ beliggaamde bewustheid van die ander. Erkenning op hierdie vlak van intersubjektiwiteit behels hierdie beliggaamde kontak met ' $n$ ander mens, waarin ' $n$ basiese maar belangrike onderskeid tussen die self en die ander gevorm word. In die Hegeliaanse paradigma is ' $n$ basiese erkenning deur ' $n$ ander nodig vir die verdieping van selfbewussyn. Dit behels die dinglike aspek van intersubjektiewe erkenning, wat vanselfsprekend blyk te wees in die sin dat dit bloot net gebeur, asof dit alreeds daar is en onmiddellik gevorm word. Dit is egter net 'n eensydige erkenning, want al wat dit bied, is 'n bewustheid dat die ander in my teenwoordigheid is, terwyl ek my as apart van die ander onderskei. Hierdie eenvoudige bewustheid bied nie kennis van myself of van die ander nie; om dit te verkry, moet 'n mens aanbeweeg na die konseptuele aspek van erkenning. Hierdie dinglike aspek is 'n aspek van bewussyn in die algemeen, dit wil sê die basiese bewustheid van verskynsels. Sodra basiese bewussyn in selfbewussyn verander het, funksioneer hierdie dinglike aspek as die element wat gevind word in beide vorme van bewussyn vanweë die niediskursiewe aard daarvan. Hegel (1949:233) se uitdrukking "gestroopte (of blote) wese" (bare existence) is hier van belang en verwys na 'n erkenning van bestaande verskynsels as sodanig, met ander woorde hoe hulle as gestroop van enige konsepte of idees voorkom. In hierdie opsig verwys verdingliking na die ervaring van verskynsels in die wêreld, wat beteken dat die wêreld deur die sintuie geken word as een (maar nie die enigste nie) aspek van ervaring.

Die dinglike aspek van Hegeliaanse erkenning, soos hier bo genoem, gaan in die eerste plek oor dit wat Hegel (1971:165) onmiddellike selfbewussyn noem. In die tweede plek speel

\footnotetext{
$5 \quad$ Ek is tot hierdie insig gebring in gesprek met Pieter Duvenage oor die onderwerp van verdingliking.
} 
dit 'n kardinale rol in die vorming van konsepte, wat vir Hegel die opkoms van selfbewussyn uit bewussyn verteenwoordig. Hierdie opkoms vind plaas voor die intersubjektiwiteit van interaksie met mense, maar verdiep binne intersubjektiewe betrokkenheid. Wat in die onmiddellike selfbewussyn op die spel is, is 'n intelligente begrip van 'n mens se bestaan. Die dinglike aspek van erkenning is die aanvanklike ervaring van selfbewussyn, wat 'n vorm van intersubjektiwiteit voorstel wat nie gedagtes of spraak benodig nie (Dien Winfield 2006:773). Volgens Dien Winfield (ibid.) bestaan die vorming van onmiddellike selfbewussyn uit twee belangrike momente: Eerstens, die moment waarin die ander (as objek) beskou word as eenders en ononderskeibaar van die self (as die objek), dit wil sê erkenning as eenvoudige bewustheid en verorbering (met ander woorde, bewussyn-as-sodanig). Tweedens, die moment waarin die besef gevorm word van die deurslaggewende onderskeid tussen die self/subjek en die ander/objek, wat ' $n$ verband lê tussen die self en die ander, dit wil sê erkenning as differensiasie (wat steeds voorkonseptuele selfbewussyn is).

Die eerste moment word gekenmerk deur 'n eenvoudige bewustheid van 'n objek (die ander) wat buite die self is. Die moment wanneer selfbewussyn posvat, is die moment waarop die beliggaamde self bewus word van 'n ander as objek. Selfbewussyn tree dan in hierdie bewustheid van die objek uit bewussyn te voorskyn. In hierdie moment word bewussyn dan selfbewussyn, hoewel dit bly by 'n eenvoudige en dierlike bewustheid van die teenwoordigheid van die ander wat bloot aangevoel word. Die grondslag van hierdie bewustheid is eenvoudige begeerte of aptyt (Hegel 1971:167). Dit is 'n belangrike waarneming oor die belangrikste bron van selfbewussyn, naamlik dat dit posvat in begeerte. Die rol van begeerte in die vorming van selfbewussyn en inderdaad erkenning kan nie onderskat word nie, want dit is by wyse van begeerte dat die self aangetrek word na 'n objek (Kojève 1969:40). Begeerte is dit wat die wil dryf om die objek te bemeester en te besit en dus eintlik om die objek af te weer, maar dit is ook deur die begeerte dat Aufhebung bereik kan word, want dit bring die nodige omstandighede mee vir die self om versoen te raak met die objek - met ander woorde die moontlikheid van wedersydse erkenning.

In hierdie stadium is iets basies en eenvoudigs ter sprake wat aan die begin van die dialektiek geposisioneer is. Die doel van onmiddellike selfbewussyn is bloot 'n opsetlike begeerte of aptyt vir die objek (Dien Winfield 2006:770). Dit wil voorkom asof dit begeerte in sy mees basiese vorm is, want volgens Dien Winfield (ibid. 771) is die verbruik van die objek die oorkoepelende doel. Die objek se funksie vir selfbewussyn in hierdie opsig is bloot om tevredenheid te weeg te bring, wat dit dus 'n objek van bevrediging vir die self maak. Selfbewussyn hier is negatief omdat dit 'n basiese bewustheid van die objek bevestig deur 'n ontkenning van die objek se subjektiwiteit, wat die objek in effek absorbeer (ibid. 772). Hierdie vorm van selfbewussyn is verder negatief omdat die erkenning van 'n ander mens nie veel verskil van die erkenning van ander objekte in die algemeen nie. Daarom word erkenning van 'n ander mens gereduseer tot erkenning van 'n objek (met ander woorde verdingliking); alles in die veld van die gegewe word dus geobjektiveer, verdinglik. As gevolg hiervan is hierdie erkenning bloot 'n oefening in objektivering, en kom dit neer op 'n basiese bewustheid. Die bewustheid van die self in die eerste moment van selfbewussyn ontstaan dus uit die objektivering van die ander. Hierdie objektivering kan die objek letterlik verslind (ibid. 772) (byvoorbeeld aan die hand van geweld of moord), of andersins deur een of ander verandering wat die objek steeds aanraak maar nie verwoes nie; dit noem Dien Winfield 'n "lesser alteration" (ibid.).

Hierdie aanraking van die objek duskant verwoesting lei na die tweede moment in die vorming van onmiddellike selfbewussyn (soos uitgewys deur Dien Winfield - hier bo), wat 
goed saamgevat word deur vier onherleibare uitgangspunte in Hegel se Fenomenologie wat Kojève (1969:39-43) identifiseer: ${ }^{6}$ Ten eerste: "The existence of the possibility of difference between the Desires of (future) Masters and the Desires of (future) Slaves" (Kojève 1969:43). Dit dek die tafel vir die konfrontasie tussen meester en slaaf asook die konflik wat moontlik kan plaasvind tussen die twee partye gebaseer op verskille in hul sienswyses en lewenswêrelde. Ten tweede: "The existence of several Desires that can desire one another mutually, each of which wants to negate, to assimilate, to make its own, to subjugate, the other Desire as Desire" (Kojève 1969:40). Dit is 'n beskrywing van die toneel in die meester-slaaf-verhouding waarin hierdie drama hom afspeel, 'n drama wat 'n wenner en 'n verloorder oplewer, en wat tot die verdere ontwikkeling van selfbewussyn lei. Ten derde: "Action that destroys or negates given Being (Action that arises from and because of Desire)" (Kojève 1969:39). Dit behels met ander woorde konseptuele objektivering van die ander wat verder gevoer word (en wat in werklikheid optree as 'n soort begeerte) deur middel van duidelike handelinge waardeur die ander 'n objek word (dus, wil ek te kenne gee, geweld van een of ander aard). Ten vierde: "The elementary possibility of revelation of Being by Speech" (Kojève 1969:39). Wese word dus in taal geopenbaar, wat dien as 'n konseptuele uitdrukking van die primêre objektivering van die ander. Ek doen aan die hand dat dit die belangrikste bron van rassisme is, naamlik die stap waar konsepte as ontkenning die plek neem van geweld of vernietiging (dus deur ' $n$ begrip van die ander). Kojève (1969:40) noem egter iets deurslaggewends, naamlik dat selfbewussyn en mense in die algemeen sal bly vasklou aan hul begeerte indien die reg om erken te word eksklusief vir een kant is (en waar erkenning dus slegs in een rigting plaasvind). Daarom sê Kojève (1969: 40) dat "Man can be fully realized and revealed - that is definitively satisfied - only by realizing a universal Recognition"; mensheid word dus volbring deur erkenning wat in beide rigtings plaasvind (albei kante erken dus en word dus erken). Dit dui op die moontlikheid van wedersydse erkenning, maar Kojève (1969:40-41) gaan voort deur te sê dat die stryd om erkenning in die begin as gevolg van hierdie veelvoud van begeertes niks anders kan wees as die stryd om lewe en dood tussen verskillende begeertes nie (dit wil sê die stryd tussen meester en slaaf se erkenning).

Hierdie tweede moment van onmiddellike selfbewussyn kom vir Hegel met die besef van die deurslaggewende differensiasie tussen self/subjek en ander/objek, wat 'n verhouding tussen die self en 'n ander vorm. Intersubjektief kan hierdie onderskeid lei tot positiewe selfbewussyn as dit aan 'n aantal vereistes voldoen: Eerstens moet daar 'n eksplisiete besef wees dat 'n objek eintlik 'n ander selfbewussyn is (Dien Winfield 2006:774), dit wil sê 'n subjek wat sy eie identiteit en betekenis kan vorm. Tweedens word 'n bewustheid van die beliggaamde verskille tussen die self en 'n ander vereis. Die rede hiervoor is dat objekte bewustelik waargeneem moet word voordat verskille deur middel van begrippe bemiddel kan word. Dit beteken dat die moment wanneer 'n selfbewussyn sigself van 'n ander onderskei, in konkrete en alledaagse kontak tussen mense moet wees. Aangesien albei 'n sin van selfbewussyn het, het elke selfbewussyn dieselfde struktuur ( ibid.) in die gedeelde erkenning dat verskille gewortel is in die beliggaamde aard van selfbewussyn. Albei neem dus deel aan die uitoefening van differensiasie waarin die verskil tussen die self en ander kenbaar word. In sekere sin verteenwoordig dit ' $n$ basiese vorm van wederkerige (of wedersydse) erkenning, maar dit gaan bloot oor 'n gevoel van onderskeid tussen die self en ander. Daarom is hierdie gevoel van

6 Ek beskou Kojève se uitgangspunte hier in die omgekeerde volgorde om die plek en vorming van rassisme spesifiek uit te lig en situeer in retrospek. Die uitgangspunte dien basies verskillende momente in 'n gesamentlike proses. 
differensiasie bloot 'n minimale wedersydse erkenning van verskille. Hierdie minimale erkenning is vlugtig en basies omdat dit 'n kwessie van eenvoudige persepsie en waarneming is, maar dit kan verder gevoer word deur intelligente, redelike en persoonlike interaksie, dit wil sê aan die hand van dialoog.

Hierdie minimale wedersydse erkenning lei tot 'n vreemde paradoks, soos verwoord deur Hegel (1971:170): "In that other as ego I behold myself, and yet also an immediately existing object, another ego absolutely independent of me and opposed to me". 'n Mens is dus bewus van jouself deur die teenwoordigheid van die ander en tog, weens sy onafhanklikheid, kan die ander jou teenstaan in die beoefening van jou subjektiwiteit (om jou eie identiteit en betekenis te vorm). Die belangrikheid van die teenwoordigheid en onafhanklikheid van die ander is die paradoks: Jy kan jou subjektiwiteit slegs deur die teenwoordigheid van die ander uitoefen, maar die ander doen dieselfde met betrekking tot sy subjektiwiteit op grond van sy onafhanklikheid van jou subjektiwiteit, dit wil sê hy benodig jou teenwoordigheid maar nie jou subjektiwiteit nie. Die resultaat hiervan is dat "either self-consciousness [has] the impulse to show itself as a free self, and to exist as such for the other:- the process of recognition" (Hegel 1970:170). Elke selfbewussyn wil dus erken word as 'n vrye wese. Hegel (ibid. 171172) voer egter aan dat hierdie proses om vry te word 'n stryd om lewe en dood is. Erkenning in sy dinglike vorm as differensiasie (die tweede moment van onmiddellike selfbewussyn) kan dus eindig met ongeveer dieselfde eindproduk as dié van erkenning as bewustheid (die eerste moment van verorbering).

Die stryd om die erkenning van die vryheid van die self geskied ten koste van die vryheid van die ander. Vir die self om vry te wees, moet die ander 'n ding word, dit wil sê die ander moet verdinglik word (en word dus in die proses verorber). Dit is die eindproduk van erkenning as bewustheid. Selfbewustheid beweeg deur die ervaring van die ooreenkomste en verskille wat dit deel met ' $n$ ander om uiteindelik dan weer terug te kom na sigself. Erkenning as differensiasie eindig egter nie met die letterlike verorbering van die objek nie. Dit lei inteendeel tot die begrip van relasionaliteit tussen subjek en objek wat vorm neem in die dialektiek van meesterskap en onderwerping (meester en slaaf). Gevolglik stop die stryd om erkenning nie by die letterlike verorbering van die ander nie, dit wil sê die ander word nie in die proses doodgemaak nie. Die resultaat van hierdie stryd is nietemin die objektivering van die ander, dit wil sê 'n terugkeer na die self. In hierdie opsig voer Hegel (1971:173) aan dat die geveg in die eerste instansie eindig as 'n eensydige ontkenning in ongelykheid. Terwyl die een vegter verkies om te lewe en so sy eie selfbewussyn te behou, maar tog wel sy eis om erkenning opgee, behou die ander sy vermoë om te onderwerp en word daarom erken as die een wat meesterskap bereik het. Die stryd om erkenning eindig met 'n eensydige erkenning, aangesien die ander sy erkenning verbeur, terwyl sy lewe in ruil daarvoor gespaar word. Uiteindelik word die opvattings oor bemeestering en onderwerping 'n bloudruk vir die maatskaplike en politieke lewe van mense. Deur Hegel (ibid.) sien ons in die stryd om erkenning en die onderwerping onder die meester op die vlak van verskynsels die opkoms van die mens se maatskaplike lewe en die begin van politieke samesyn.

\section{RASSISME EN DIE PROBLEEM VAN KOLONIALE BEWUSSYN}

Die opvattings gestel in Hegel se meester-slaaf-dialektiek is in die werk van Frantz Fanon bevestig as die letterlike werklikheid van menseverhoudinge in die moderne kolonialisme wat deur Europa gevoer is in die res van die wêreld. Wat belangrik is om in ag te neem, is dat selfbewussyn en die erkenning daarvan (van die self en die ander) bestaan uit momente wat 
in 'n konseptuele vorm moontlik as rassisme versterk kan word. As 'n ander dus as objek aan die dood ontkom, kan geweld hom steeds op verskillende maniere aangedoen word. Tog beteken dit nie dat die dialektiek op elke vlak identies werk nie. Die interaksie tussen individue is nie iets wat bloot na die kollektiewe uitgebrei kan word nie. Die abstrakte proses (soos ek dit hier bo op 'n ietwat gedehistoriseerde manier skets) het te make met 'n proses van toenemende spanning tussen teenoorgestelde kante, maar daar bestaan wel verskillende moontlikhede op maatskaplike en politieke vlak wat hierdie spanning progressief kan oorkom. In hierdie afdeling word 'n oorsig gegee van koloniale bewussyn as een moontlikheid, wat lei tot 'n (moderne) koloniale mentaliteit in die self en 'n vervreemde selfbewussyn in die ander.

My interpretasie van Hegel se dialektiek en die meester-slaaf-verhouding (hier bo, maar veral in die volgende afdelings) is gesetel in 'n postkoloniale perspektief (dus in die lig van die Europese kolonialisme wat tot 'n einde gekom het in die middel van die 20ste eeu), en derhalwe 'n posisie wat konflik en geweld as 'n sosiopolitieke werklikheid beskou, maar ook poog om 'n brug uit hierdie situasie te vind (of ten minste om die problematiek van wedersydse erkenning in hierdie konteks te verstaan). Hierdie standpunt word verwoord in Sekyi-Otu (1996:28-29) se (post)koloniale beskrywing van die dialektiek wat die dinamiese en nierasionele beweging daarvan beklemtoon. Ek volg Sekyi-Otu om die meester-slaaf-verhouding te sien as 'n punt op die lyn van die dialektiek wat loop na Aufhebung en meer progressiewe vorme wat nie noodwendig so eksplisiet polities is as 'n veldslag om lewe en dood nie. Ek voer aan dat hierdie beweging die moontlikheid van wedersydse erkenning vereis en dat dit inderdaad tot stilstand kom as dit nie gebeur nie. Die meester-slaaf-verhouding beskryf die mislukking van wedersydse erkenning by Hegel (Anderson 2009:116), wat Anderson (ibid.) beskou as 'n opsetlike skuif deur Hegel binne die groter prentjie van Fenomenologie, maar terselfdertyd stel hy die voorwaardes wat wedersydse erkenning moontlik kan maak. Dit is ook die vertrekpunt vir Axel Honneth (1995) se kernwerk oor wedersydse erkenning en in plaas daarvan om die meester-slaaf-verhouding te benader as die standaard vir die stryd om erkenning, ondersoek hy Hegel se vroeë werke om 'n teorie van wedersydse erkenning te ontwikkel waarmee 'n mens inderdaad verby wanerkenning na die Aufhebung kan beweeg. ${ }^{7}$ Hierdie Aufhebung lyk wel anders as die een in die postkoloniale konteks (wat 'n soort Fanoniaanse Aufhebung is, sien hier onder) omdat dit verbind word met 'n geïdealiseerde vorm wat vooraf bepaal is, soos wat die geval is met Honneth se drieledige erkenningsmodel wat in liefde, legitimiteit (regte) en solidariteit gewortel is (Bird-Pollan 2015:88). Die postkoloniale Aufhebung neem eerder in situ vorm aan, dit wil sê langs die kontoer van die historiese situasie.

My aanwending van Hegel om rassisme en vervreemde selfbewussyn beter te verstaan, stem ooreen met die siening (soos gestel deur Gordon 1995:23) dat 'n lyn getrek kan word van Rousseau, deur Hegel, Marx en Sartre, tot by Fanon, wat tesame 'n diskoers oor vervreemde sosialiteit uitmaak. Fanon het byvoorbeeld Sartre se denke in Being and Nothingness benader as 'n beskrywing van vervreemde bewussyn, wat as sodanig die menslike realiteit korrek

7 Ek neem elders Honneth se teorie in gesprek met Fanon onder die loep om dit te toets in die postkoloniale konteks (sien Villet 2018). In teenstelling met Honneth se benadering word die bron van die moontlike vraagstukke van wedersydse erkenning in hierdie artikel gevind in Hegel se later werke ná Fenomenologie in plaas van sy vroeë werke, soos wat Honneth dit gebruik in The Struggle for Recognition (1995). Die rede is dat ek soek na 'n weg verby meester en slaaf na wedersydse erkenning, wat nie Honneth se doel is nie. Daar is slegs 'n paar verwysings na die meester-slaaf-dialektiek in sy analise (ibid. 62-63, 145 en 147). 
opsom mits dit beskou word in die lig van die beskrywing (ibid.). Hier volg ek dan in Fanon se voetspore met 'n soortgelyke beskrywing van Hegel se meester-slaaf-dialektiek in die poging om Hegel uit te daag aan die hand van sy eie standpunte. Dit is ook om dié rede dat die bespreking in die vorige afdeling benader is as 'n uiteensetting van die kognitiewe wortels van rassisme, met ander woorde dit wat in die selfbewussyn aanleiding gee tot rassisme in die interaksie tussen die self en die ander. Ek sou wat hierdie taak betref om rassisme binne die self-ander-raamwerk te ontleed, pace Fanon ook gebruik kon maak van Lewis Gordon se werk (wat Fanon in gesprek met Sartre oor die self in oënskou neem) of dié van Nelson MaldonadoTorres (Fanon in gesprek met Levinas oor die ander). My keuse het geval op Fanon in gesprek met Hegel, en ek poog om hier 'n bydrae te maak tot navorsing oor Hegel deur aan te toon dat hy tog wel 'n redelik uitgebreide weergawe bied vir 'n fenomenologie van rassisme. Dit plaas dan Hegel se weergawe van die meester-slaaf-dialektiek in 'n ander lig, alhoewel dit tog 'n beskrywende eerder as ' $n$ normatiewe model vir menseverhoudinge is; dit het egter normatiewe implikasies (wanneer 'n mens dit deur die bril van kolonialisme lees). Markell (2003:119) bied 'n bondige samevatting van die plek van die meester-slaaf-dialektiek wat my posisie goed situeer, naamlik dat dit gesien moet word as 'n metafoor wat sekere algemene eienskappe van sosiale oorheersing illustreer en nie as die enigste konkrete vorm van wanerkenning nie (alhoewel dit tog resoneer met moderne koloniale slawerny soos beoefen deur Europese moondhede kort voor die aanvang van die 20ste eeu).

Wanneer hierdie dinamiek van die meester-slaaf-dialektiek sigself wel manifesteer in die samelewing (soos Hegel dit beskryf het as 'n spesifieke toedrag van sake), word dit 'n ernstige probleem omdat dit die dryfveer is van verskillende vorme van vooroordeel en onderdrukking. In hierdie opsig het Hegel 'n soortgelyke weergawe gelewer van konflik en twis as 'n vertrekpunt vir menseverhoudinge as dié van Machiavelli (in The Prince) en Hobbes (in Leviathan). Hierdie weergawes is suksesvol as beskrywings van menslike samelewings, maar dit laat steeds die normatiewe taak om 'n soort oplossing te konseptualiseer waarmee hierdie toedrag van sake hanteer kan word (Machiavelli stel slinkse manipulasie voor en Hobbes die sosiale kontrak). So 'n oplossing sal ook die problematiek wat die dialektiek meebring, moet oplos. Dit lyk asof hierdie problematiek diep gewortel is in die idee van die Hegeliaanse bewussyn, soos hier bo geïllustreer. 'n Mens moet egter regverdig teenoor Hegel wees en erken dat hy bloot 'n beskrywing verskaf. Hy gee egter wel 'n paar idees oor die manier waarop die verhouding tussen meester en slaaf hanteer kan word. Sy beskrywing onthul die dinamiek van 'n problematiese tipe menslike verhouding. In 'n neutedop: Die meester-slaaf-verhouding is 'n voortsetting van voorkonseptuele minimale erkenning maar nou in konseptuele terme. Konsepte neem die plek van die letterlike verorbering van die objek in, in hierdie geval 'n ander mens wat verdinglik word. Hierdie vorm van intersubjektiwiteit lei dan tot 'n vervreemde selfbewussyn by dié wat verdinglik word, naamlik die slaaf.

Die probleem met hierdie vorm van intersubjektiwiteit volgens die Hegeliaanse bewussyn het sy oorsprong in twee aannames in sy werk: Eerstens, vir Hegel "all human behaviour in the material world, and hence all human history, is rooted in a prior state of [human] consciousness", dit wil sê op die vlak van idees (volgens Fukuyama 1989); en tweedens, die integrale rol wat intersubjektiewe erkenning in die opkoms van selfbewussyn speel. Hierdie aannames fokus op die kern van Hegel se weergawe van menslike verhoudings en beteken dat daar ernstig gedink moet word oor wat Hegel te sê het van die meester-slaaf-dialektiek (met inbegrip van die onderliggende aannames), oor die soort bewussyn wat daarby betrokke is, en oor wat dit onthul van 'n verklaring vir die teenwoordigheid van rassisme en geweld in menseverhoudinge. Dit beteken nie dat ek Hegel se aannames as kategoriese elemente van 
menseverhoudinge aanvaar nie, maar ter wille van die proses en denkrigting van die gang van die geskiedenis sedert sy tyd is dit nodig om die moontlike gevolgtrekkings van sy denkrigting ernstig op te neem. Hegel motiveer die eerste van bogenoemde aannames deur 'n voorbeeld van die tweede aanname wat hy maak, naamlik die meester-slaaf-dialektiek. Deur middel van hierdie voorbeeld onthul hy dat "the realm of consciousness in the long run necessarily becomes manifest in the material world, indeed creates the material world in its own image" (Fukuyama 1989). Die toestand van die menslike bewussyn (en die mens se idees van die wêreld) sal dus lei tot' 'n sekere tipe aardse werklikheid. Wat intersubjektiwiteit betref, is dit vanselfsprekend dat die toestand van menslike bewussyn (en die idees wat dit genereer) 'n diepgaande uitwerking op menseverhoudinge het.

Dit is dus daarom belangrik om die plek van rassisme binne die dialektiek te kwalifiseer. Met ander woorde, waarom neem wanerkenning van die (kollektiewe) ander die vorm van rassistiese geweld aan? Dit is inderdaad so dat wanerkenning nie net die gevolg van slegs rassisme is nie; dit kan verskeie vorme aanneem, onder andere klassedifferensiasie en blote onderdrukking. Die konteks van moderne Europese kolonialisme is in hierdie opsig belangrik en die beskrywing van die dialektiek in hierdie essay karteer die raamwerk van 'n soort koloniale mentaliteit wat noodwendig lei tot rassisme. Dit is dus 'n beskrywing van 'n sekere vorm wat wanerkenning kan aanneem, alhoewel dit nie die enigste vorm is nie. Hierdie koloniale mentaliteit het sy oorsprong in moderne koloniale tye en die eerste interaksie tussen Europa en mense op die ander kontinente wat daarna gekolonialiseer is, maar tog is dit ' $n$ mentaliteit wat hedendaags steeds voortleef in postkoloniale tye, in die Weste en in voormalige kolonies. In die postkoloniale konteks is hierdie mentaliteit byvoorbeeld nog aanwesig in Europa waar mense, ten spyte van die einde van formele kolonialisme, steeds praat oor Afrika in koloniale terme (dink maar aan die "Africa is a Country"-debat). Hierdie koloniale mentaliteit het ook in Suid-Afrika die vorm aangeneem van 'n soort welstandsrassisme (gebaseer op ekonomiese klas wat langs raslyne loop), wat lei tot ekonomiese vorme van neo-apartheid (elders neem ek dit breedvoerig onder die loep; sien Villet 2018).

Die kern van hierdie mentaliteit word opgesom deur Fanon self in Black Skin, White Masks, waarin hy aanvoer dat die standaard vir volle menslike wasdom die wit vel is, wat die maatstaf word vir dié wat nie 'n wit vel het nie. Dit wat aan swart mense in die wit spieël teruggereflekteer word, is altyd iets wat hulle kortkom, naamlik hul eie vryheid en individualiteit, en hul eie liggaam word in die lig hiervan geïnstrumentaliseer (deur die wit setlaar en hulself) omdat dit anders is en nie wit nie (1986:212). Fanon toon aan dat hierdie instrumentalisering radikaal is omdat dit 'n mens (die swart man of vrou) neem en hom of haar dan ontmens, en boonop nog verdierlik tot 'n soort "masjien-dier-mens" (ibid. 220). Die swart mens is dus nie volwaardig mens nie en dit is die kruks van wanerkenning as rassisme, wat dan ook lei tot hulle onderdrukking en tot die geweld waaraan hulle onderwerp word. Hierdie rassistiese geweld is 'n noodwendige uitkoms van die meester-slaaf-dialektiek (tussen die self en die ander) binne die konteks van kolonialisme en die koloniale mentaliteit wat sig postkoloniaal manifesteer, alhoewel daar wel ook ander manifestasies van onderdrukking en konflik kan wees (op die grondslag van nasionaliteit, klas, geslag of seksuele oriëntasie).

Die kernbeweging wat binne die moderne koloniale konteks of mentaliteit plaasvind, is die een van verdingliking na verdierliking. Mbembe (2001:209) dui in hierdie opsig aan dat Hegel in The Philosophy of History beweer dat mense in Afrika nie oor die vermoë beskik om selfbewustheid te bereik nie en dat hulle daarom eerder permanent verkeer in die onmiddellike wese wat 'n toestand van barbaarsheid onderskryf - kortom, 'n lewe en bestaan wat in baie opsigte dierlik is. Mbembe (ibid. 192-193) toon verder aan dat die meester-slaaf-dialektiek 
binne die koloniale (en ook postkoloniale) konteks noodwendig lei tot 'n proses van verdierliking waarvolgens die inheemse bevolking (in Afrika) soos diere benader word sonder enige respek vir hulle menslikheid. Gevolglik kan die setlaar sigself nie identifiseer met die inheemse bevolking nie, veral nie met hulle wese nie, en daarom betoon die setlaar geen meegevoel met dié wat gekolonialiseer is nie. Dit is trouens die punt van hierdie proses van verdierliking, naamlik om die setlaar die reg te gee om die inheemse bevolking te behandel soos diere. Mbembe (ibid. 193-194) gaan so ver as om kolonialisme en die behandeling van sogenaamde Eerste Nasies (ook genoem Inheemse Volke of Aboriginale Volke; in Engels First Peoples) te vergelyk met 'n jagtog of strooptog waarin nie net hulle liggame nie, maar ook hulle geskiedenis verdierlik word.

Hierdie verdierliking is binne die koloniale konteks van Afrika die vergestalting van 'n radikale verdingliking wat die swart mens reduseer tot niks meer nie as 'n blote objek, wesenlik afgesny van hul menslikheid, wat Fanon (1986:109) bestempel as crushing objecthood. Hierdie gebrek aan wese (nonbeing) impliseer ook dat die mense wat gekolonialiseer word, nie beskik oor 'n wese vir ander nie (Hegel se being for others) en meer nog, enige ontologiese bestaan word eintlik vir hulle ontoeganklik binne 'n "beskaafde" koloniale samelewing (ibid.). Hierdie opvatting van die swart mens as 'n ras sonder wese verskaf die regverdiging vir imperiale kolonialisme en slawerny. Ras word dan die onderbou van die meester-slaaf-verhouding en dit laat die rassistiese geweld van die dialektiek in verskeie vorme voortleef. ${ }^{8}$ Die onderliggende koloniale mentaliteit wat dit ondersteun, skep 'n wêreld waarin bewussyn vervreem is van mensheid in sowel die self as die ander. Dit is ook die punt van Fanon se analise in Black Skin, White Masks, naamlik dat sowel die onderdrukker as die onderdrukte mense in die koloniale samelewing skade ly. Die wit onderdrukker se vervreemding neem die vorm aan van die koloniale mentaliteit en die ontkenning van die ander se mensheid, onderwyl die onderdrukte swart mens 'n selfbewussyn vorm wat hom vervreem van sy eie mensheid. Hierdie beweging in die dialektiek word in die finale analise gereflekteer in die verandering in terminologie oor die dialektiek vanaf Hegel se heer en kneg na die meester en slaaf. In Hegel se weergawe kan daar steeds moontlik 'n gees van welwillendheid wees, maar dit verdwyn in die moderne koloniale konteks, waar verontmensliking en verdierliking die slaaf in die gesig staar.

Om hierdie argument saam te vat en te verbind aan die bespreking in die voorafgaande afdeling (oor verdingliking en begrip), kan 'n kritieke leemte rakende die geval van die meester en slaaf geïdentifiseer word (wat veral belig word in die werk van Fanon). Die reaksie van die meester op die slaaf (en ook andersom) bring 'n bewussyn tot stand wat idees, dit wil sê konsepte, as primêr en allerbelangriks beskou. Daarom sal die slaaf verbind word tot ' $n$ idee wat die meester in sy bewussyn het, dit wil sê 'n konseptuele erkenning. Dit beteken dat die slaaf se idee oor homself nie sy eie maaksel is nie. Die aard van die selfbewussyn wat by die slaaf (maar ook by die meester) na vore kom, behels gevolglik 'n verhouding van vervreemding (dit was die fokus van Marx se herinterpretasie van Hegel) en die ontwikkeling van vervreemde selfbewussyn. Hierdie soort selfbewussyn hou twee sleutelprobleme in: Eerstens, die afwesigheid of ontkenning van mensheid in die selfbewussyn, waar dit betrekking het op verhoudinge met die ander en wat gemanifesteer word as die raamwerk van ras; en tweedens, die idees wat gegenereer word as gevolg van hierdie afwesigheid/ontkenning, wat verbind word aan die ras van die ander en spesifiek lei tot wanherkenning. Hierdie idees word soms

\footnotetext{
8 Die verskillende tipes rassegeweld wat Fanon in die koloniale konteks identifiseer, word goed uiteengesit deur Jinadu (2003:44-50), naamlik fisiese, institusionele en sielkundige geweld.
}

Tydskrif vir Geesteswetenskappe, Jaargang 61 No. 3: September 2021 doi.10.17159/2224-7912/2021/v61n3a14 
saamgevat in enkele terme of woorde (etikette). Goeie historiese voorbeelde hiervan is die alombekende terme "nigger" (in Amerika en Europa, maar ook elders) en "kaffer" (veral in Suid-Afrika), wat as gevolg van moderne kolonialisme en slawerny mettertyd rassistiese skelwoorde geword het met spesifieke verwysing na swart mense soos wat dit gebruik is deur Europese setlaars. Hierdie probleme motiveer die koloniale mentaliteit in die self, wat in hierdie essay aangebied word as 'n manifestasie van die meester-slaaf-dialektiek in die moderne koloniale en die postkoloniale konteks.

Hegel karteer die ontwikkeling van hierdie soort selfbewussyn en dit is van deurslaggewende belang dat hierdie proses met die oog op die skets van wedersydse erkenning wat hier onder volg, reg begryp word. Die belangrikheid van sy weergawe van die meester-slaafverhouding is dat dit ' $n$ verklaring vir rassisme fasiliteer. Gibson (2003:30) bevestig dit wanneer hy sê: "Fanon's introduction of race into the master/slave dialectic is a profound though largely overlooked original contribution developed in the context of the postwar 'Hegel' in France." Hierdie oorspronklike bydrae ('n Fanoniaanse moment in die dialektiek) moet ook in ag geneem word as daar gekyk word na die kwessie van wedersydse erkenning en hoe Fanon die belangrike rol van rassisme en geweld in die stryd om erkenning uitwys ('n kwessie wat Hegel duidelik verwaarloos het $){ }^{9}$

\section{DIE MOONTLIKHEID VAN WEDERSYDSE ERKENNING}

Hegel het wel sekere idees geopper oor die moontlikheid van wedersydse erkenning (ná die meester-slaaf-dialektiek) in sy sogenaamde "sillogisme van erkenning", aldus Williams (1997:59). Hierdie (taamlik ingewikkelde) sillogisme onthul waar die meester-slaaf-dialektiek 'n mislukking van wedersydse erkenning word (Hegel 1977:112):

In this movement [of two self-consciousnesses] we see repeated the process which presented itself as the play of Forces, but repeated now in consciousness. What in that process was for us, is true here of the extremes themselves. The middle term is selfconsciousness which splits into the extremes; and each extreme is this exchanging of its own determinateness and an absolute transition into the opposite. Although, as consciousness, it does indeed come out of itself, yet, though out of itself, it is at the same time kept back within itself, is for itself, and the self outside of it, is for it. It is aware that it at once is, and is not, another consciousness, and equally that this other is for itself only when it supersedes itself as being for itself, and is for itself only in the being-for-self of the other. Each is for the other the middle term, through which each mediates itself with itself and unites with itself; and each is for itself, and for the other, an immediate being on its own account, which at the same time is such only through this mediation. They recognize themselves as mutually recognizing one another.

In hierdie belangrike paragraaf voer Hegel, aldus Williams, aan dat die interaksie tussen twee selfbewussyne dieselfde weg volg as die rudimentêre wisselwerking tussen subjek en objek, dit wil sê tussen konsep en verskynsel (begrip en ding). Die aangehaalde gedeelte hier bo is belangrik omdat dit aanvoer dat wedersydse erkenning moontlik is, al is dit net as ideaal. Hegel (1977:112) noem bogenoemde die "suiwer begrip van erkenning" (pure Notion of

$9 \quad$ Ek bring Fanon se analise van Hegel se meester-slaaf-dialektiek elders breedvoerig onder die loep (sien Villet 2011). 
recognition), dit wil sê erkenning in basiese terme. Dit beteken dat wedersydse erkenning in teorie moontlik is, maar soos Hegel se meester-slaaf-dialektiek in die werklikheid ontwikkel, is intersubjektiwiteit gebaseer op twis en konflik in plaas van die wederkerigheid van wedersydse erkenning. Op grond van bogenoemde "sillogisme van erkenning" blyk dit dat selfbewussyn die potensiaal dra vir die wedersydse erkenning van 'n ander. Die verwesenliking van hierdie potensiaal vereis drie belangrike aangeleenthede wat in die selfbewussyn moet ontwikkel:

1. Selftransendensie: Dit is 'n term wat Williams (1997:59) gebruik in sy bespreking van bostaande sillogisme om die beweging tussen twee selfbewussyne te beskryf. Dit dui op die beduidende rol van selfbewussyn as 'n poging om uit te reik na 'n ander selfbewussyn. In hierdie uitreikingsbeweging gee mens jouself die kans om verder te vorder as blote vooroordeel en vooropgestelde idees. Dit lei tot 'n transendensie van die self en 'n openheid teenoor die ander.

2. Bemiddeling: Dit is 'n broodnodige moment, want "each is the mediating term for the other, through which each mediates itself with itself and coincides with itself" (Hegel in Williams 1997:59). Dit beteken dat bemiddeling 'n sin van gemeenskap tussen twee persone vereis, dit wil sê elkeen soek gemeenskaplike grond waar die ander tegemoetgekom kan word (byvoorbeeld die mensheid van die self en die ander).

3. Wederkerigheid: Dit word benodig om te verseker dat die erkenning wat bereik word, nie eensydig is nie (dit wil sê wanerkenning wat voorgehou word as wedersydse erkenning). Hierdie wederkerigheid impliseer dat 'n mens jouself moet gade slaan in die erkenning van 'n ander, terwyl die ander dieselfde moet doen. Die resultaat hiervan is 'n wedersydse vryheid waarin 'n ware vorm van die self wasdom vind.

Williams (1997:59) voer baie sinryk aan dat 'n mens slegs 'n volledige sin van die self kan verkry deur onderlinge erkenning. Dit lyk asof hy impliseer dat enigiets minder as wedersydse erkenning 'n mens 'n onvoldoende sin van jou self gee, met ander woorde 'n self wat nie ten volle ontwikkel is nie. Selfbewussyn is belangrik omdat dit die potensiaal verteenwoordig vir die wedersydse erkenning tussen die self en 'n ander (soos hier bo genoem). 'n Spanning ontstaan egter in die selfbewussyn as gevolg van die wisselwerking tussen subjek en objek, wat Williams bestempel as die paradoks van Hegel se sillogisme (ibid.). Selfbewussyn kan die ekstreme roete volg deur 'n ander te objektiveer as heeltemal anders as die self en terselfdertyd sy eie identiteit op 'n ander afdwing (ibid.). Dit beteken dat die ander die identiteit van sy ander as meester moet erken, terwyl hy sy identiteit as slaaf moet aanvaar soos op hom deur die meester afgedwing. Vir Hegel (1977:116) is dit 'n ongelyke erkenning van opposisie waarin die een selfbewussyn (naamlik die meester) erken word, terwyl die ander (naamlik die slaaf) eenvoudig erkenning gee maar dit nie self ontvang nie. Dit is die bedrieglike en onegte erkenning, wat Williams $(1997: 59,64)$ bestempel as valse erkenning (phony recognition), dus erkenning wat van die een kant af op die ander afgedwing word.

Daarenteen kan selfbewussyn die bemiddelingsroete van 'n samesmelting van sy eie belange en dié van 'n ander volg. In hierdie geval bevestig selfbewussyn die subjektiwiteit en vryheid van 'n ander, wat sy eie subjektiwiteit en vryheid, ironies genoeg, versterk (omdat sy identiteit nie uitsluitlik afhanklik is van sy identiteit as meester nie). Dit maak die deur oop vir wedersydse erkenning en die belangrike beweging weg van die totstandkoming van die subjek-objek-verhouding tussen mense. In plaas daarvan het 'n mens dan 'n ware gevoel van intersubjektiwiteit, dit wil sê wedersydse subjektiwiteit. Wedersydse subjektiwiteit impliseer dat die identiteit van selfbewussyn sy eie maaksel is en nie deur ' $n$ ander op hom afgedwing 
word nie. Dit is hoe die sogenaamde Aufhebung plaasvind, dit wil sê om 'n gemeenskaplike standpunt te bereik wat beide partye kombineer terwyl die ou verhouding van ongelykheid en ongeregtigheid iets van die verlede word.

Hoe sal hierdie Aufhebung in die lig van moderne kolonialisme (en die koloniale mentaliteit) lyk? Die vervreemding van menswees veronderstel dat 'n persoon eens mens is of was. Daarom sal die Aufhebung begin deur die ontmensliking van swart mense (maar ook die gepaardgaande vervreemding in die gewese wit onderdrukkers) so te hanteer dat hulle menswees herstel kan word (dus 'n proses van rehumanisering) aan die hand van wedersydse erkenning. Dit beteken dat wedersydse erkenning nie net op papier moet plaasvind nie, maar ook in die letterlike werklikheid tussen die self en die ander, tussen wit en swart, tussen onderdrukker en onderdrukte. Wedersydse erkenning sal net op papier bly indien daar nie aandag gegee word aan hierdie rehumanisering nie; dit bepleit Fanon in sy gevolgtrekking in The Wretched of the Earth, waar hy na nuwe moontlikhede van menswees en 'n nuwe soort mens aan die ander kant van kolonialisme verwys (1965:251-255). ${ }^{10}$ Wedersydse erkenning as 'n soort rehumanisering moet aandag gee aan die koloniale mentaliteit van die wit mens, wat anders is maar tog wel ook die spieëlbeeld van die swart mens se vervreemde selfbewussyn. Slegs dan kan ware wedersydse erkenning 'n moontlikheid in die letterlike en aardse werklikheid word. Die pleidooi in die volgende afdeling oor hoe ons wanerkenning kan aanpak (en moontlik sielkundig / kognitief kan behandel), moet dus gelees word in die lig van hierdie soort "Fanoniaanse Aufhebung", wat moet verseker dat wedersydse erkenning fokus op die rehumanisering van sowel die self as die ander. ${ }^{11}$ Wat belangrik is om hier in ag te neem, is dat die konsep van ras vir Fanon 'n soort padblokkade op pad na erkenning is (Bird-Pollan 2015:88), dit wil sê ras en rassisme as wanerkenning (ibid.). Die rehumanisering hier ter sprake is dus net moontlik deur die Aufhebung (sublasie) van 'n spesifieke historiese toestand of situasie ( ibid.) wat deur ras en rassisme gedomineer word.

\section{SLOT: HOE KAN ONS WANERKENNING AANPAK?}

Valse erkenning (dit wil sê wanerkenning) is duidelik 'n geval van die subjek-objek-verhouding wat deur middel van konseptuele denke in menslike verhoudinge gemanifesteer word waar een party verdinglik (of selfs verdierlik word), wat dan lei tot 'n reïfikasie van die verhouding. Williams (1997:69) voer tereg aan dat Hegel die negatiewe dimensies van erkenning ondersoek, dit wil sê weiering, dwang en misleiding. Hy sinspeel egter wel op die moontlikheid van wedersydse erkenning. Die weergawe van die meester-slaaf-dialektiek wat in Fenomenologie verskyn, gee egter die weergawe van 'n spesifieke vorm van bewussyn wat ondermynend en vernietigend is (ibid.). Dit is 'n problematiese weergawe van intersubjektiwiteit omdat dit die fundamentele onderskeid tussen 'n konsep en bepaalde sigbare vorme daarvan laat vervaag in plaas daarvan om dit te behou. Williams (1997:73) wys daarop dat hierdie

$10 \quad$ Fanon het inderdaad gewaarsku teen blote erkenning op papier in sy kritiek op Sartre se hantering van vervreemde bewussyn en erkenning (in Being and Nothingness). Hy voer aan dat dit net van toepassing is op verhoudinge tussen volwaardige mense, dus die wit mens of Europeër. Fanon wys daarop dat ons in ag moet neem dat die swart man se beliggaamde lyding as slaaf anders is as dié van die wit mens as meester. Daarom is Sartre se greep op die ander en vervreemde selfbewussyn nie van toepassing op swart bewussyn nie (1986:138).

11 Sekyi-Otu (1996:26) se idee van 'n Fanoniaanse ervaringsdialektiek gee ook 'n aanduiding van die meer progressiewe vorme wat die dialektiek kan aanneem deur hierdie Aufhebung wat poog om by kolonialisme verby te beweeg. 
problematiek sentraal in die dialektiek staan: "Hegel himself tends to blur this distinction somewhat because he discusses recognition as if master/slave were an integral aspect of it, rather than a contingent, deficient exemplification of [the] possibilities [of recognition]." Dit lyk asof Hegel se kategoriese bespreking van die meester-slaaf-verhouding hom oopstel vir kritiek, maar Williams dui aan dat Hegel in die Ensiklopedie III: Filosofie van die Gees (gepubliseer in 1830) wel die pad uit die meester-slaaf-dialektiek na wedersydse erkenning vind. In hierdie werk beweer Hegel dat erkenning nie noodwendig konflik en opposisie behels nie (Williams 1997:74). In die geval van die meester en slaaf word erkenning vertraag omdat konflik en opposisie kenmerkend van die verhouding is.

Wat wel duidelik is, is dat Hegel die rol van geweld en rassisme binne die meester-slaafdialektiek nie voldoende oorweeg het nie. Die rol van veral rassisme bly latent in Hegel se weergawe van die verhouding. Dit kan wees dat ras (en rassisme) bloot 'n blinde kol in Hegel se dialektiek was, maar dit speel wel 'n dubbelsinnige rol binne Hegel se weergawe van die meester-slaaf-dialektiek. ${ }^{12}$ Hegel verwys wel na die stryd om lewe en dood wat plaasvind voordat die identiteit van die meester en slaaf gevorm word, waarna die meester die een is wat die ander se identiteit konseptueel bepaal aan die hand van begrippe. Hy verwys verder na die identiteitsontwikkeling wat plaasvind in die selfbewussyn van die slaaf, wat verkry word aan die hand van strawwe arbeid (waarmee die slaaf op die ou end sy vryheid kan verkry). Hegel het egter nie die implikasies van die dinamiek van elk van hierdie momente in die dialektiek volledig deurdink nie. Dit plaas die fokus op die problematiese dinamiek wat binne die dialektiek geïdentifiseer word, naamlik die vae onderskeid tussen konsep en verskynsel. Die rol van konseptuele denke in die verskynsels wat dit beskryf, moet in ag geneem word, en die allerbelangrike rol wat Hegel aan begrippe verleen, belet hom om die gevolge van die meester-slaaf-dialektiek volledig te besef.

Dit laat die mislukking van wedersydse erkenning, dit wil sê wanerkenning, en hier is dit belangrik om drie moontlike voorstelle rakende Hegel se teks te maak indien hierdie mislukking aangepak moet word. Hierdie drie voorstelle is nie noodwendig oorspronklik nie, maar kan die kern vorm van die problematiek wat in Hegel se weergawe van die meester-slaaf-dialektiek

12 Die rassistiese ondertone in Hegel se werk is alombekend, hoewel dit nie noodwendig van kardinale belang vir die kritiese analise van sy dialektiek is nie. Ek beskou dit tog as 'n blinde kol wat wel die meester-slaaf-dialektiek in konteks plaas en wat ook 'n analise daarvan aan die hand van rassisme regverdig. Die werk van Bernasconi is veral instruktief aangaande Hegel se "rassisme", wat ondersteun is deur die tydsgees. Die trant van Hegel se werk beskou Europa as die eindpunt van geskiedenis (Bernasconi 2000:171), terwyl Afrika geen bydrae het om tot wêreldgeskiedenis te lewer nie. Hegel se eie idees oor ander rasse verskyn deurlopend in sy Lectures on the Philosophy of History en laasgenoemde standpunt verskyn juis daar in soveel woorde (Hegel 2011:91), byvoorbeeld waar hy praat van die "Afrika-ras" en almal op die kontinent oor die selfde kam skeer (ibid::88).

'n Lang voetnota verskyn ook in die Ensiklopedie III: Filosofie van die Gees waarin Hegel (1971:41-45) verwys na Afrika en Haiti as deel van 'n argument dat Kaukasiese denke (wat begin in Asië en eindig in Europa) die eerste vergestalting is van die gees se absolute eenheid met sigself en ook dat die karakter van konkrete universele en selfvormende denke spesifiek gevind word in Europese en Christelike denke (ibid.:45). Hy verwys neerhalend na rasse van die ander kontinente en kom tot die gevolgtrekking dat die Europese gees in opposisie staan tot 'n wêreld wat sigself wil toe-eien deur die ander deel te maak van die eenheid wat Europese denke vorm (ibid::46). Bernasconi (2000:190-191) kom ook tot hierdie gevolgtrekking oor Hegel se denke en meen dat dit ' $n$ implisiete regverdiging vir kolonialisme in die 19de eeu verskaf en vir Europeërs die reg gegee het om mense van ander rasse te behandel soos hulle wou. 
voorkom. Die drie voorstelle vorm my tesis vir 'n sekere perspektief op die meester-slaafdialektiek:

1. As uitgangspunt, na aanleiding van Williams (1997:60), sou 'n mens die meesterslaaf-dialektiek kon beskou as 'n gebrekkige realisering van die proses van erkenning. Williams stel dit soos volg: "[The master-slave] is a determinate instance of recognition that is unequal: one party recognizes the other but is not recognized in turn, and the other is recognized but does not recognize." Williams (ibid.:73) beweer egter dat die meester-slaaf-dialektiek eenvoudig 'n voorwaardelike maar gebrekkige voorbeeld van die moontlikhede van erkenning is.

2. As aanvaar word dat dit die geval is, moet 'n mens vra waaruit hierdie gebrekkige besef van erkenning bestaan. Hier stel ek voor dat dit as 'n soort (moderne) koloniale mentaliteit die tipe selfbewussyn is wat rassisme en geweld onderlê. In hierdie opsig volg ek Fanon se voorbeeld om die meester-slaaf-dialektiek te benader as 'n weergawe van die ontwikkeling van vervreemde selfbewussyn, dit wil sê selfbewussyn wat gekenmerk word deur rassisme en uitgedruk word deur geweld (hoewel nie uitsluitlik so nie) en deur die vervreemding van mensheid binne die self en die ander.

3. Indien die eerste twee voorstelle aanvaar word, moet daar verder gevra word waar die probleem in Hegel se weergawe van selfbewussyn lê wat vervreemding en gevolglik rassisme en geweld teweegbring. Na my mening het dit te make met die verband tussen twee belangrike sake binne die Hegeliaanse paradigma, naamlik verskynsel en konsep. Hierdie verhouding blyk problematies te wees as dit gaan oor intersubjektiewe erkenning en die verhoudinge tussen persone, dit wil sê wanneer dit spesifiek oor die verskynsel van ras gaan en hoe dit verband hou met rassistiese konsepte. Hegel het nie die bedreiging van rassisme en geweld ten volle in ag geneem wat die verhouding tussen meester en slaaf betref nie.

Hierdie voorstelle moet gesien word in die lig van die dialektiese proses en verder gekontekstualiseer word as 'n proses wat vorm aanneem aan die hand van kolonialisme. Die meesterslaaf-dialektiek is per definisie 'n ongelyke verhouding waarin onderwerping en oorheersing in die dinamiek van hierdie verhouding sentraal staan. Daar is dus geen ander vorm wat hierdie verhouding kan aanneem nie, tensy daar deur Aufhebung 'n beweging weg van dié verhouding af is na 'n progressiewer vorm. Wat beklemtoon moet word, is dat hierdie vordering deur die slaaf gedra word, want hy is die ondergeskikte en bevind hom in 'n slegter situasie. Daar is geen rede vir die meester om hierdie stap te doen nie. Die wêreld of maatskaplike werklikheid van hierdie verhouding is die slaaf se juk, aangesien hy die arbeid verrig om dinge te maak, wat weer bydra tot 'n gevoel van selfgemaakte selfbewussyn. Aan die hand van slawerny ontwikkel slawe hul bewussyn as 'n groep of klas, wat dan die eerste stap in 'n eis om erkenning is. Hierdie klassebewussyn word nie van die individu af uitgebou nie, maar ontwikkel uit die kollektiewe groep en word tot 'n werklikheid omskep. Dit is 'n beweging wat nie by die meester plaasvind nie. Hierdie beweging na erkenning van die slaaf beweeg deur vervreemde selfbewussyn, en die slaaf moet eintlik hierdie beweging in al sy vorme (stoïsyns, skepties, ongelukkig, aldus Hegel in Fenomenologie (1977:119-138)) deurmaak om die punt te bereik waar selfbewussyn 'n eis om wedersydse erkenning kan begin (wat ook rassisme en geweld kan pak).

Volgens bogenoemde voorstelle is die sentrale aanname dat Hegel se weergawe van die meester-slaaf-dialektiek, en die selfbewussyn wat daaruit voortvloei, beskou kan word as 'n weergawe van die opkoms van wanerkenning as rassisme soos uiteengesit in hierdie essay. 
Rassisme en geweld is konkrete gevolge van die wisselwerking tussen meester en slaaf soos dit in die werklikheid van 'n moderne koloniale en postkoloniale konteks gemanifesteer word as gevolg van 'n sogenaamde koloniale mentaliteit. Die proses van erkenning en hoe dit ontwikkel van selferkenning na eensydige erkenning (dus wanerkenning) en uiteindelik na wedersydse erkenning word in onderstaande tabel voorgestel:

TABEL 1: $\quad$ Erkenning en rassisme in Hegel se bewussynsteorie

\begin{tabular}{|l|l|l|l|}
\hline & Tipe erkenning: & Kognitiewe proses: & Bewussynsvlak: \\
\hline $\begin{array}{l}\text { Interaksie met } \\
\text { die wêreld }\end{array}$ & Selferkenning & $\begin{array}{l}\text { Onderskei dinge } \\
\text { (wêreld en realiteit) }\end{array}$ & $\begin{array}{l}\text { Bewussyn (van blote of } \\
\text { gestroopte bestaan) }\end{array}$ \\
\cline { 3 - 4 } & $\begin{array}{l}\text { Onderskei tussen } \\
\text { dinge (self en ander) }\end{array}$ & $\begin{array}{l}\text { Verdieping van } \\
\text { bewussyn (as } \\
\text { selfbewustheid) }\end{array}$ \\
\hline $\begin{array}{l}\text { Intersubjekti- } \\
\text { witeit (interaksie } \\
\text { met persone) }\end{array}$ & $\begin{array}{l}\text { Wanerkenning } \\
\text { (eensydig) }\end{array}$ & $\begin{array}{l}\text { Onderskei ander as } \\
\text { ding }\end{array}$ & $\begin{array}{l}\text { Koloniale mentaliteit } \\
\text { en vervreemde } \\
\text { selfbewussyn (rassisme } \\
\text { en geweld) }\end{array}$ \\
\cline { 2 - 4 } & $\begin{array}{l}\text { Wedersydse } \\
\text { erkenning }\end{array}$ & $\begin{array}{l}\text { Onderskei ander as } \\
\text { vry } \\
\text { (as subjek) }\end{array}$ & $\begin{array}{l}\text { Vrye selfbewussyn } \\
\text { (openheid tot die ander) }\end{array}$ \\
\hline
\end{tabular}

Selfbewussyn onderskei en identifiseer objekte in die wêreld en hierdie vlak van bewussyn kan beskou word as blote bestaan (gestroop van konsepte of begrip). Daar is dan ' $n$ verdieping van bewussyn tot selfbewustheid waarin die self onderskei word van die wêreld, en hier word die skeuring aangetref wat plaasvind tussen die self as subjek en die wêreld (of ander) as objek. Wanerkenning as eensydige erkenning is basies 'n voortsetting van objekgerigte erkenning in menseverhoudinge waarin 'n ander persoon bloot as 'n objek (en ding) onderskei word. Dit gee aanleiding tot koloniale bewussyn, dit wil sê die koloniale mentaliteit van die self wat vervreemde selfbewussyn in die ander begrond, en die verhoudinge van rassisme en geweld wat daarin gebaseer is. Dit gee vorm aan 'n verhouding waarin die ander oorheers word deur die self, en wel in so 'n mate dat hulle van mekaar vervreem word, terwyl die ander ook vervreemd voel van die wêreld om hulle en van hul eie mensheid omdat hulle gevoel van vryheid deur iemand anders beheer word. Ideale interaksie met die ander, waarin die kardinale probleme van rassisme en geweld aangepak kan word, sou 'n vorm van wedersydse erkenning wees wat die ander as 'n gerehumaniseerde subjek onderskei (dit wil sê 'n bevryde persoon wat sy/haar eie identiteit kan vorm en nie onderwerp word nie). In hierdie verband vind 'n mens ook die ideale voorwaardes vir selfkennis vir sowel die self as die ander. Hierdie moment van Aufhebung in die dialektiek se gang is broodnodig as 'n weg om die wanerkenning in die meester-slaaf-verhouding te oorkom, maar dit is ook 'n postkoloniale Aufhebung wat anders daar uitsien as wat Hegel in die oog gehad het. 


\section{BIBLIOGRAFIE}

Anderson, S. 2009. Hegel's theory of recognition: From oppression to ethical liberal modernity. London: Continuum.

Bernasconi, R. 2000. With what must the philosophy of world history begin? On the racial basis of Hegel's Eurocentrism. Nineteenth century contexts, 22.2:171-201.

Bird-Pollan, S. 2015. Hegel, Freud and Fanon: The dialectic of emancipation. New York: Rowman \& Littlefield International.

Dien Winfield, R. 2006. Self-consciousness and intersubjectivity. The Review of Metaphysics, 59(June):757-779.

Fanon, F. 1986 [1952]. Black skin, white masks (transl. CL Markman). London: Pluto Press.

Fanon F. 1967 [1961]. The wretched of the earth (transl. C Farrington). London: Penguin Books.

Fukuyama, F. 1989. “The end of history?". The National Interest (Summer). http://www.wesjones.com/ eoh.htm [9 April 2021].

Gibson, NC. 2003. Fanon: The postcolonial imagination. Cambridge: Polity Press.

Gordon, LR. 1995. Fanon and the crisis of European man: An essay on philosophy and the human sciences. New York: Routledge.

Hegel, GWF. 1949 [1807]. The phenomenology of mind (transl. JB Baille). London: Allen and Unwin.

Hegel, GWF. 1971 [1830]. Philosophy of mind (Part III of Encyclopaedia of the philosophical sciences) (transl. JN Findlay). Oxford: Clarendon Press.

Hegel, GWF. 1977 [1807]. Phenomenology of spirit (transl. AV Miller). Oxford: Oxford University Press.

Hegel, GWF. 2011 [1837]. Lectures on the philosophy of history (transl. R Alvarado). Aalten: Wordbridge.

Hobbes, T. 1886 [1651]. Leviathan: Or the matter, form and power of a commonwealth, ecclesiastical and civil ( $2^{\text {nd }}$ edition). London: George Routledge and Sons.

Honneth, A. 1995. The struggle for recognition: The moral grammar of social conflicts (transl. J Anderson). Cambridge, Massachusetts: The MIT Press.

Jinadu, A. 2003. Fanon: In search of the African revolution. London: Kegan Paul.

Kojève, A. 1969 [1947]. Introduction to the reading of Hegel: Lectures on the Phenomenology of Spirit (ed. A Bloom, transl. JH Nichols). Ithaca, New York: Cornell University Press.

Machiavelli, N. 2003 [1532]. The prince (transl. R Goodwin). Boston: Dante University Press.

Markell, P. 2003. Bound by recognition. Princeton: Princeton University Press.

Mbembe, A. 2001. On the postcolony. Los Angeles: University of California Press.

Sartre, J. 2003 [1943]. Being and nothingness: A phenomenological essay on ontology (transl. H Barnes). London: Routledge.

Sekyi-Otu, A. 1996. Fanon's dialectic of experience. Cambridge, Massachusetts: Harvard University Press.

Taylor, C. 1994. Multiculturalism: Examining the politics of recognition. Princeton, New Jersey: Princeton University Press.

Villet, C. 2011. Hegel and Fanon on the question of mutual recognition: A comparative analysis. The Journal of Pan-African Studies, 4.7 (November):39-51.

Villet, C. 2018. The South African heterotopia: Whiteness and the postcolonial struggle for recognition beyond apartheid. Melbourne: Monash University (unpublished $\mathrm{PhD}$ thesis).

Williams, RR. 1997. Hegel's ethics of recognition. Berkeley \& Los Angeles: University of California Press. 